doi:10.18575/msrs.sm.e.16.21 UDK 502.3:504.5]:614.71(497.6) COBISS.RS-ID 6164248

\section{Air Pollution Effect on Morbidity of the Population of the Republic Of Srpska}

\section{ABSTRACT}

Introduction: Air pollution is caused by the emission of harmful gaseous and particulate matter, resulting mainly from human activity, but also by emission from natural sources.

Aim of the Study: The aim of this study was to investigate the most common air pollutants in the Republic of Srpska region (one of the entities in Bosnia and Herzegovina) and their effect on population health, as well as to compare the obtained results with the European and world data.

Patients and Methods: We used a descriptive study approach to analyze the health of the population in the Republic of Srpska, through data obtained by the Public Health Institute of the Republic of Srpska, for the five-year period.

Results: The population of the Republic of Srpska is mostly affected by circulatory system diseases, followed by neoplasms.

Conclusion: Bearing in mind the pathophysiological mechanisms by which air pollution is involved in the onset and exacerbation of cardiovascular, respiratory, cancer and other diseases, as well as their representation in our population, one can draw a parallel between the air quality in the Republic of Srpska and the trend of the morbidity of its population.

Key words: air pollution, morbidity, particulate matter.

(Scr Med 2016:47:125-130)

\section{Andreja Figurek, ${ }^{1}$ Aleksandra Figurek ${ }^{2}$}

${ }^{1}$ Internal Medicine Clinic, University Clinical Centre of the Republic of Srpska, Banja Luka, the Republic of Srpska, Bosnia and Herzegovina ${ }^{2}$ Faculty of agriculture, University of Banja Luka, Banja Luka, the Republic of Srpska, Bosnia and Herzegovina

\section{Kontakt adresa:}

Andreja Figurek

Akademika Jovana Surutke 9

7800 o Banja Luka

Republic of Srpska

Bosnia and Herzegovina

E-mail:andrejafigurek@yahoo.com

Telephone: +38765668626

Fax: +38751660040

Submitted: July $20^{\text {th }}, 2016$

Accepted: August 15 ${ }^{\text {th }}, 2016$

\section{Introduction}

The emission of harmful gaseous and particulate matter causes an air pollution, which occurs mainly as a result of human activity, but also by the emission from natural sources. Air pollution occurs when the concentrations of certain pollutants reaches the levels of potentially toxicity, i.e. for human health as well as for plants and animals. Air pollutants may be categorized as: "primary air pollutants" i.e. those pollutants directly emitted to the atmosphere by some pollution source (e.g. from vehicle exhaust or chimneys), and the "secondary air pollutants" i.e. those formed in the atmosphere as a result of reactions (oxidation and transformation) between the primary pollutants, e.g. the secondary particulate matter and ozone. ${ }^{1}$ Particulate matter (PM) is a widespread air pollutant that consists of a mixture of solid and liquid particles suspended in the air. ${ }^{2}$

Primary particles, originating from combustion sources, usually are consisted of a carbonaceous core with 
chemicals (such as sulfates, metals and polycyclic aromatic hydrocarbons) absorbed to their surfaces. Secondary particles are formed by chemical reactions in the atmosphere of primary particles with gases (such as nitric oxides, ozone and sulfur oxides, which are strong oxidants), leading to the formation of nitrates and ammonia. According to the size of the particles, the PMs are classified as 1) PM10, i.e. those with particles aerodynamic diameter less than 10 micrometres; 2) PM2.5, i.e. those with particles diameter less than 2.5 micrometres (also known as fine particulates) and 3) PMo.1, i.e. those particles with diameter less than 0.1 micrometres - also known as ultrafine particulates. ${ }^{2}$ The PMs are known to be harmful to human health. ${ }^{3}$

Exposure to air pollution can have acute and chronic effects. Acute exposure can cause: mortality, increased respiratory symptoms, decreased lung function, effects on plasma viscosity, heart rate variability, pulmonary inflammation and hospitalization or other health care visits. Effects of chronic exposure to air pollution are increased mortality rates, reduced survival times, chronic cardiopulmonary disease and reduced lung function. The most susceptible are elderly, infants, persons with chronic cardiopulmonary disease, pneumonia, influenza and asthma. ${ }^{4}$

It is known that air pollution can cause worsening of the respiratory diseases. Moreover, other diseases can be caused and/or worsened by air pollution, primarily neoplasms and circulatory diseases. Therefore, the aim of this study was to investigate the most common air pollutants in the Republic of Srpska and their effect on population health, as well as the comparison the obtained results with the European and world data.

\section{Patients and Methods}

We used a descriptive study approach to analyze the health of the population of the Republic of Srpska, through data obtained by the Public Health Institute of the Republic of Srpska, for the period 2009-2013. The study involved around 1.4 million people (inhabitants of the Republic of Srpska). These data were compared with guidelines thresholds suggest by World Health Organisation as well as with data (Eurpean and world level) published by other authors.

\section{Results}

The main air pollutants in the Republic of Srpska were: PM1O and PM2.5, nitrogen oxides, ozone (O3), sulphur dioxide (SO2), polycyclic aromatic hydrocarbons (PAH), benzene, 1,3-butadiene, carbon monoxide (CO) and lead $(\mathrm{Pb})$.

According to the Gazette of the Republic of Srpska, air quality categories shall be determined according to the level of pollution, starting with the prescribed limit and tolerance values defined in Regulation on the values of air quality (Fig. Gazette of RS, no. 124/12), as well as on the basis of the measurement results. If there is no prescribed tolerance limit for a pollutant, its value is taken as the tolerance value. Categories of air quality are determined once a year for the previous calendar year. The following table presents air quality in relation to the averaging period. In order to protect human health, limit values as well as tolerance limits has been established.

Table 1. Air quality in relation to the averaging period

\begin{tabular}{|c|c|c|c|c|}
\hline Pollutants & The average period & Limit & Tolerance limit & Margin of tolerance \\
\hline \multirow{3}{*}{$\mathrm{SO}_{2}$} & 1 hour & $350 \mu \mathrm{g} / \mathrm{m}^{3}(1)$ & $150 \mu \mathrm{g} / \mathrm{m}^{3}$ & $500 \mu \mathrm{g} / \mathrm{m}^{3}$ \\
\hline & 24 hours & $125 \mu \mathrm{g} / \mathrm{m}^{3}(2)$ & & $125 \mu \mathrm{g} / \mathrm{m}^{3}$ \\
\hline & calendar year & $50 \mu \mathrm{g} / \mathrm{m}^{3}$ & & $50 \mu \mathrm{g} / \mathrm{m}^{3}$ \\
\hline \multirow{3}{*}{$\mathrm{NO}_{2}$} & 1 hour & $150 \mu \mathrm{g} / \mathrm{m}^{3}(3)$ & $75 \mu \mathrm{g} / \mathrm{m}^{3}$ & $225 \mu \mathrm{g} / \mathrm{m}^{3}$ \\
\hline & 24 hours & $85 \mu \mathrm{g} / \mathrm{m}^{3}$ & $40 \mu \mathrm{g} / \mathrm{m}^{3}$ & $125 \mu \mathrm{g} / \mathrm{m}^{3}$ \\
\hline & calendar year & $40 \mu \mathrm{g} / \mathrm{m}^{3}$ & $20 \mu \mathrm{g} / \mathrm{m}^{3}$ & $60 \mu \mathrm{g} / \mathrm{m}^{3}$ \\
\hline \multirow{2}{*}{ PM10 } & 24 hours & $50 \mu \mathrm{g} / \mathrm{m}^{3}(4)$ & $25 \mu \mathrm{g} / \mathrm{m}^{3}$ & $75 \mu \mathrm{g} / \mathrm{m}^{3}$ \\
\hline & calendar year & $40 \mu \mathrm{g} / \mathrm{m}^{3}$ & $8 \mu \mathrm{g} / \mathrm{m}^{3}$ & $48 \mu \mathrm{g} / \mathrm{m}^{3}$ \\
\hline \multirow{3}{*}{$\mathrm{CO}$} & 8 hours & $10 \mathrm{mg} / \mathrm{m}^{3}$ & $6 \mathrm{mg} / \mathrm{m}^{3}$ & $16 \mathrm{mg} / \mathrm{m}^{3}$ \\
\hline & 24 hours & $5 \mathrm{mg} / \mathrm{m}^{3}$ & $5 \mathrm{mg} / \mathrm{m}^{3}$ & $10 \mathrm{mg} / \mathrm{m}^{3}$ \\
\hline & calendar year & $3 \mathrm{mg} / \mathrm{m}^{3}$ & & $3 \mathrm{mg} / \mathrm{m}^{3}$ \\
\hline
\end{tabular}

Source: Regulation on the values of air quality (Gazette of RS, no. 124/12)

Legend:

(1): not to be exceeded more than 24 times in a calendar year.

(2): not to be exceeded more than 3 times in one calendar year.

(3): not to be exceeded more than 18 times in a calendar year.

(4): not to be exceeded more than 35 times in a calendar year. 
Graph 1. presents the population health structure and the most common causes of death among population in the Republic of Srpska.

\section{Graph 1. Deaths by causes of death ${ }^{5}$}

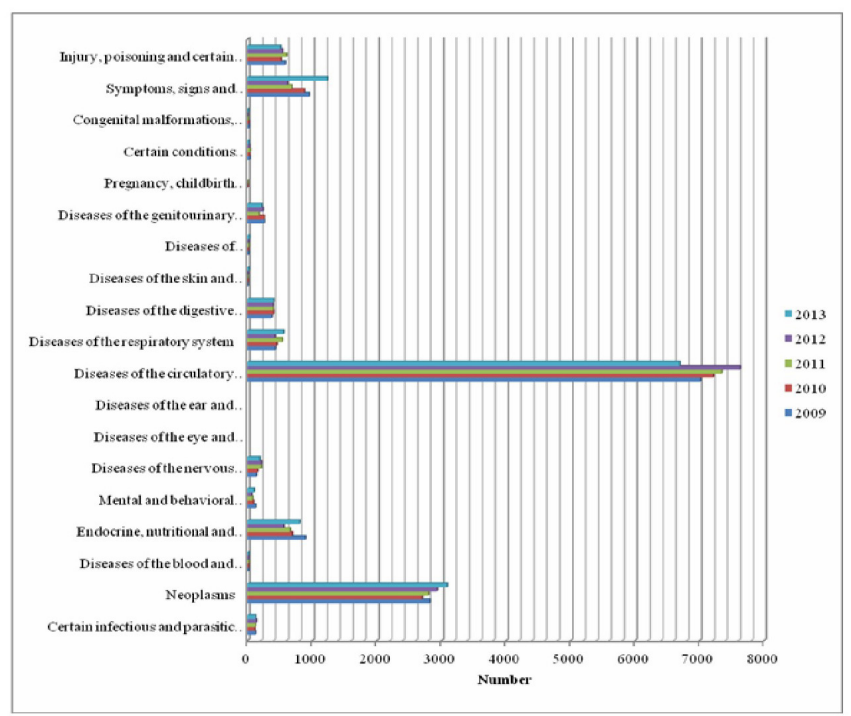

It can be seen that population of the Republic of Srpska is mostly affected by circulatory system diseases, followed by neoplasms. The overall mortality rate was 1042.98 per 100.000 for men and 921.32 per 100.000 for women. The most common causes of death were: diseases of the circulatory system (6687), neoplasms (3090), endocrine, nutritional and metabolic disease (800) and diseases of the respiratory system (556). ${ }^{5}$ The percentage of deaths caused by diseases of the respiratory system is on the rise, and it is about $4 \%$ in the total death.

\section{Discussion}

Even short-term exposure to low levels of pollutants can damage lungs at the cellular level. For instance: sulfuric acid compounds and ozone may hinder the immune system's ability to defend against infection. ${ }^{6}$ Ozone is a highly reactive gas that triggers oxidative stress when it enters the airways. Air quality and air pollution affect not only human respiratory system, but also the whole organism. Air pollution is now becoming an independent risk factor for cardiovascular morbidity and mortality with molecular mechanisms for PM-caused cardiovascular disease that include direct toxicity to cardiovascular system or indirect injury by inducing systemic inflammation and oxidative stress in peripheral circulation. ${ }^{7}$ Due to the size and chemical composition of PMo.10, it is much easier to cross the pulmonary epithelium and the lung-blood barrier and accumulate in blood. ${ }^{7}$ After deposit on vascular endothelium, PMo.10 can aggravate the local oxidative stress and inflamation, resulting the atherosclerotic plaque instability, and finally may lead to thrombus formation. ${ }^{8}$
Increased oxidative stress and activated inflammatory pathway in pulmonary due to exposure to PM particulate play a substantial role in the indirect pathway.7

Considerable evidence has proved that particulate air pollutants can trigger an inflammation related cascade when they deposit in the lung,,9,10 resulting in increased circulating level of pro-inflammatory cytokines such as CRP, IL-6, IL-8 and IL-1 $\beta .{ }^{11}$ Systemic inflammatory is a well-known risk factor for atherosclerosis progression, and this pro-inflammatory mediators are close related to increased blood coagulability and endothelial dysfunction and which finally can exacerbate myocardial ischemia. ${ }^{7}$

Numerous findings indicate that even a few hours to weeks of short-term exposure to PM particulates can trigger cardiovascular disease-related mortality and events, especially among the susceptible individuals at great risk including the elderly or the patients with preexisting coronary artery disease. ${ }^{7}$ The results of study performed by Raza et al. suggest that short-term elevations of $\mathrm{O}_{3}$ urban background levels are associated with an increased risk of out-of-hospital cardiac arrest with no indication of a threshold level, in a region with $\sim 50 \mathrm{mg} / \mathrm{m} 3$ annual $\mathrm{O}_{3}$ levels. ${ }^{12}$

Two-hour exposure to particles was associated with an increased risk of ventricular arrhythmias in patients with implantable cardioverter devices, pointing to the possible importance of shorter exposure periods..$^{13}$

$\mathrm{Li}$ and colleagues found an increase of $10 \mu \mathrm{g} / \mathrm{m} 3$ in twoday moving average concentrations of particulate matter $\leq 10 \mu \mathrm{m}$ in aerodynamic diameter (PM10), sulfur dioxide (SO2) and nitrogen dioxide (NO2) was significantly associated with increases of $0.36 \%, 0.86 \%$ and $1.30 \%$ in daily coronary heart disease mortality in 8 Chinese cities, respectively, with pooled exposure-response curves that were almost linear and no apparent thresholds were identified. ${ }^{14}$

Air pollution is associated with markers of inflammation, coagulation and endothelial activation. Hajat et al. showed that $5 \mu \mathrm{g} / \mathrm{m}$ increase in long-term ambient PM2.5 was associated with $6 \%$ higher interleukin-6 and increase in long-term NO was associated with $7 \%$ higher level of D-dimer, making these data consistent with the hypothesis that long-term exposure to air pollution is related to some markers of inflammation and fibrinolysis. ${ }^{15}$ Multicenter study of 11 European cohorts pointed to an association between long-term exposure to PM constituents and coronary events. ${ }^{16}$

Ozone is thought to increase cardiovascular death rates in high-risk groups by inducing damage in pulmonary mast cells. ${ }^{17}$ The impacts of ozone on nonaccidental, cardiovascular and possibly cerebrovascular mortality 
increases during summer, and is amplified during the warmest days..$^{18}$ According to European environmental agency, 95\% of the total EU urban population is exposed to ozone levels exceeding the World Health Organization (WHO) Air Quality Guidelines (AQG). ${ }^{19}$

Air pollution guidelines and legal limits have generally not been based on cardiovascular outcomes. For example, WHO recommends that average levels of PM1O $(24 \mathrm{~h}$ average), ozone ( $8 \mathrm{~h}$ average), sulphur dioxide ( $\mathrm{SO} 2)(24 \mathrm{~h}$ average) and nitrogen dioxide (NO2) (1 h average) should not exceed 50, 100, 20 and $200 \mathrm{mg} / \mathrm{m}_{3}$, respectively, but these limits were derived principally from data on mortality (for PM10 and ozone) and respiratory outcomes among vulnerable individuals (for $\mathrm{SO}_{2}$ and $\mathrm{NO}_{2}$ ).

Research on mortality rates in heavily polluted areas reveals statistically significant links between high levels of air pollutants and increased numbers of deaths, primarily among the elderly. ${ }^{20}$

Results from 23 European cities/areas of the APHEA 2 project (Air Pollution and Health: A European Approach) show that, in warm season, a $10 \mathrm{mg} / \mathrm{m} 3$ increase in the 1-hour and in 8-hour ozone concentration was associated with a $0.5 \%$ significant increase in the daily number of cardiovascular deaths, with the larger effects observed in the southern cities. ${ }^{21}$

Some data suggest that exposure to particulate matter may be associated with decreased birth weights. ${ }^{22,23} \mathrm{An}$ ecological study of infant mortality and air pollution was conducted in the Czech Republic in the period 1986-1988, where Bobak et al. found a weak positive associations between neonatal mortality and total suspended particulates (TSP-10) and $\mathrm{SO} 2 .{ }^{24}$

Hwang and Chan (2002) reported that, in Taiwan, the rates of daily clinic visits for lower respiratory tract illness were associated with current-day concentrations of nitrogen dioxide, carbon monoxide, sulfur dioxide and particulate matter less than or equal to $10 \mu \mathrm{m} .{ }^{25} \mathrm{~A}$ study in Boston population, performed by Mostofsky et al. (2012), showed that the association between higher concentration of PM2.5 particles and higher risk of ischemic stroke. ${ }^{26} \mathrm{Pac}$ et al. (2013) found that mean daily PM10 level higher than $50 \mu \mathrm{g} / \mathrm{m} 3$ increased asthma-related hospital morbidity in Poland, with sulfur dioxide shown to be the most important predictor. ${ }^{27} \mathrm{~A}$ study in the United Kingdom performed by Sofianopoulou et al. (2013) indicated that an increse of 10 $\mu \mathrm{g} / \mathrm{m} 3$ in ambient PM10 was associated with an increse of $1 \%$ in salbutamol prescribing, showing that monthly respiratory prescribing in primary care is a useful indicator of the extent to which air pollution exacerbates asthma and chronic obstructive pulmonary disease (COPD) symptoms. ${ }^{28-32}$
WHO air quality annual guidelines suggest the limit for PM10 to be less than $20 \mu \mathrm{g} / \mathrm{m}^{3}$ for European Member States. However, in the year 2010 this limit had been accomplished only by 9 of the 34 Member States. Bosnia and Herzegovina had set a limit slightly less than $50 \mu \mathrm{g} /$ $\mathrm{m}^{3} .^{2}$ When we talk about PM2.5, Bosnia and Herzegovina had set a concentration of PM2.5 in the range 10-15 $\mu \mathrm{g} /$ m3 for the year 2005, ${ }^{29}$ while WHO air quality annual guidelines suggest the limit to be $10 \mu \mathrm{g} / \mathrm{m}^{3}{ }^{2}$

Emissions of primary PM2.5 have reduced by about a third for both the European Environment Agency member countries 2013 (EEA-33) and the European Union member countries (EU-28) compared to their levels in 1990. More importantly, the timeline of emissions reductions shows that the EEA-33, as a whole, is on track towards achieving the total reduction target implied by the Gothenburg Protocol. However, country-specific PM2.5 timelines suggest that not all countries are on track to meet their individual commitments by 2020. These countries may therefore need to implement emissions reduction measures beyond those currently applied..$^{30-32}$

\section{Conclusion}

It is estimated that approximately $3 \%$ of cardiopulmonary and $5 \%$ of lung cancer deaths are attributable to PM globally. In the European Region, this proportion is $1-3 \%$ and $2-5 \%$, respectively, in various subregions. ${ }^{31}$ Our research showed that the most common air pollutants in Republic of Srpska are secondary particles. Also, in the Republic of Srpska most patients were suffering from cardiovascular diseases and neoplasms. Therefore, the impact of air pollution and the occurrence of these diseases can lead to interconnection.

Results emerging from a recent study indicate that the burden of disease related to ambient air pollution may be even higher. This study estimates that in 2010, ambient air pollution, as annual PM2.5, accounted for 3.1 million deaths and around $3.1 \%$ of global disability-adjusted life years (DALY). ${ }^{32}$

Exposure to PM2.5 reduces the life expectancy of the population for about 8.6 months on average. Results from the scientific project "Improving Knowledge and Communication for Decision-making on Air Pollution and Health in Europe" (Aphekom), which uses traditional health impact assessment methods, indicate that average life expectancy in the most polluted cities could be increased by approximately 20 months if the long-term PM2.5 concentration was reduced to the WHO (AQG) annual level. ${ }^{2}$

When it comes to air quality, Bosnia and Herzegovina, and therefore the Republic of Srpska did not reach the quality of air recommended according to the WHO guidelines. 
Bearing in mind the pathophysiological mechanisms by which air pollution is involved in the onset and exacerbation of cardiovascular, respiratory, cancer and other diseases, as well as their representation in our population, one can draw a parallel between the air quality in the Republic of Srpska and the trend of the morbidity of its population. However, there are limitations in this study, in terms of precise data, due to the lack of accurate data because of absence of the recent census in the Republic of Srpska and Bosnia and Herzegovina.

\section{Reference}

1. European Environment Agency. Air quality in Europe-2014 report. No 5/2014. pp 80. ISSN 1977-8449. doi:10.2800/22775.

2. World Health Organisation. Health Effects of particulate matter. Policy implications for countries in eastern Europe, Caucasus and central Asia. 2013. ISBN 9789289000017. Available from: http://www.euro.who.int/__data/assets/ pdf_file/ooo6/189051/Health-effects-of-particulatematter-final-Eng.pdf?ua=1.

3. WHO 2016. World Health Organisation Fact Sheet. Available from: http://www.who.int/mediacentre/factsheets/fs313/ en/.

4. Arden Pope III C. Epidemiology of fine particulate air pollution and human health: biologic mechanisms and who's at risk? Environmental Health Perspectives.2000;108:Suppl 4 .

5. Public Health Institute of the Republic of Srpska. Analysis of population health in Republic of Srpska. Banja Luka. 2013. Available from: http://www.phi.rs.ba/pdf/publikacije/ publikacija_zdr_stanje_2013.pdf.

6. Lippman M. Health Effects of Ozone: A Critical Review. JAPCA. 1989;39(5):672-95.

http://dx.doi.org/10.1080/o8940630.1989.10466554

7. Du Y, Xu X, Chu M, et al. Air particulate matter and cardiovascular disease: the epidemiological, biomedical and clinical evidence. J Thorac Dis 2016;8(1): E8-E19. PMid:26904258 PMCid:PMC4740122

8. Kilinç E, Van Oerle R, Borissoff JI, et al. Factor XII activation is essential to sustain the procoagulant effects of particulate matter. J Thromb Haemost 2011;9:1359-67. http://dx.doi.org/10.1111/j.1538-7836.2011.04280.x PMid:21481175

9. Huang W, Wang G, Lu SE, et al. Inflammatory and oxidative stress responses of healthy young adults to changes in air quality during the Beijing Olympics. Am J Respir Crit Care Med 2012;186:1150-9.

http://dx.doi.org/10.1164/rcem.201205-0850OC

PMid:22936356 PMCid:PMC3530204

10. Seagrave J. Mechanisms and implications of air pollution particle associations with chemokines. Toxicol Appl Pharmacol 2008;232:469-77.

http://dx.doi.org/10.1016/j.taap.2008.08.001

PMid:18755206 PMCid:PMC2585747
11. Meier R, Cascio WE, Ghio AJ, et al. Associations of short-term particle and noise exposures with markers of cardiovascular and respiratory health among highway maintenance workers. Environ Health Perspect 2014;122:726-32.

http://dx.doi.org/10.1289/ehp.1307100

12. Raza A, Bellander T, Bero-Bedada G, et al. Short-term effects of air pollution on out-of-hospital cardiac arrest in Stockholm. Eur Heart J 2014;35:861-8.

http://dx.doi.org/10.1093/eurheartj/eht489

PMid:24302272

13. Ljungman PL, Berglind N, Holmgren C, Gadler F, Edvardsson N, Pershagen G, Rosenqvist M, Sjogren B, Bellander T. Rapid effects of air pollution on ventricular arrhythmias. Eur Heart J 2008;29:2894-2901.

http://dx.doi.org/10.1093/eurheartj/ehn463 PMid:19004842

14. Li H, Chen R, Meng X, et al. Short-term exposure to ambient air pollution and coronary heart disease mortality in 8 Chinese cities. Int J Cardiol 2015;197:265-70.

http://dx.doi.org/10.1016/j.ijcard.2015.06.050 PMid:26142971

15. Hajat A, Allison M, Diez-Roux AV, et al. Long-term exposure to air pollution and markers of inflammation, coagulation, and endothelial activation: a repeat-measures analysis in the Multi-Ethnic Study of Atherosclerosis (MESA). Epidemiology 2015;26:310-20.

http://dx.doi.org/10.1097/EDE.0000000000000267 PMid:25710246 PMCid:PMC4455899

16. Wolf K, Stafoggia M, Cesaroni G, et al. Long-term Exposure to Particulate Matter Constituents and the Incidence of Coronary Events in 11 European Cohorts. Epidemiology 2015;26:565-74.

http://dx.doi.org/10.1097/EDE.ooooooooooooo300 PMid:25978793

17. Parodi S, Vercelli M, Garrone E, et al. Ozone air pollution and daily mortality in Genoa, Italy between 1993 and 1996. Public Health. 2005; 119(9):844-50.

http://dx.doi.org/10.1016/j.puhe.2004.10.007

PMid:16039938

18. Pascal M, Wagner V, Chatignoux E, et al. Ozone and short-term mortality in nine French cities: Influence of temperature and season. Atmospheric Environment. 2012; 62:566-72.

http://dx.doi.org/10.1016/j.atmosenv.2012.09.009

19. European Environment Agency. Emissions of the main air pollutants in Europe. Available from: http://www.eea. europa.eu/data-and-maps/indicators/main-anthropogenicair-pollutant-emissions/assessment.

20. Schwartz J, Dockery D. Increased Mortality in Philadelphia Associated with Daily Air Pollution Concentrations. Am Rev Respir Dis. 1992; 145(3):600-4. http://dx.doi.org/10.1164/ajrcem/145.3.60o PMid:1546841

21. Gryparis A, Forsberg B, Katsouyanni K, et al. Acute effects of ozone on mortality from the "Air Pollution and Health: a European Approach" project. American Journal of Respiratory and Critical Care Medicine. 2004;170:1080- 
7 . http://dx.doi.org/10.1164/rccm.200403-333OC PMid:15282198

22. Ha EH, Lee JT, Kim H, et al. Infant susceptibility of mortality to air pollution in Seoul, South Korea. Pediatrics. 2003;111(2):284-90. http://dx.doi.org/10.1542/peds.111.2.284

23. Kaiser R, Romieu I, Medina S, et al. Air pollution attributable postneonatal infant mortality in U.S. metropolitan areas: A risk assessment study. Environmental Health. 2004;3(1):4. http://dx.doi.org/10.1186/1476-069X-3-4 PMid:15128459 PMCid:PMC420482

24. Bobak M, Leon DA. Air pollution and infant mortality in the Czech Republic, 1986-88. Lancet. 1992; 340(8826):1010-4. http://dx.doi.org/10.1016/0140-6736(92)93017-H

25. Hwang JS, Chan CC. Effects of air polution on daily clinic visits for lower respiratory tract illness. Am J Epidemiol. 2002;155(1):1-10. http://dx.doi.org/10.1093/aje/155.1.1

26. Mostofsky E, Schwarz J, Coull BA, et al. Modeling the association between particle constituents of air pollution and health outcomes. Am J Epidemiol. 2012; 176(4):31726.

http://dx.doi.org/10.1093/aje/kwso18 PMid:22850792 PMCid:PMC3491968

27. Pac R, Majewska P, Gorynski. Asthma-related hospital morbidity in relation to air pollution in Malopolska region,
Poland. European Journal of Public Health.2013; 23(suppl 1)ckt123.128. DOI:10.1093/eurpub/ckt123.128

28. Sofianopoulou E, Rushton SP, Diggle PJ, et al. Association between respiratory prescribing, air pollution and deprivation, in primary health care. Journal of Public Health. 2013;35(4):502-9.

http://dx.doi.org/10.1093/pubmed/fdt107 PMid:24293452

29. Brauer M, Amann M, Burnett RT, et al. Exposure assessment for estimation of the global burden of disease attributable to outdoor air pollution. Environmental Science and Technology. 2012; 46:652-60.

http://dx.doi.org/10.1021/es2025752

PMid:22148428 PMCid:PMC4043337

30. European Environment Agency. Available from: http:// www.eea.europa.eu/data-and-maps/data/data-viewers/airemissions-viewer-lrtap (accesed 21.10.2015).

31. Cohen AJ, Ross Anderson H, Ostro B, et al. Urban air pollution. In: Ezzati M et al., eds. Comparative quantification of health risks. Global and regional burden of disease attributable to selected major factors. Geneva. World Health Organization. 2004, 2(17):1354-433.

32. Lim SS, Vos $\mathrm{T}$, Flaxman $\mathrm{AD}$ et al. A comparative risk assessment of burden of disease and injury attributable to 67 risk factors and risk factor clusters in 21 regions, 19902010: a systematic analysis for the Global Burden of Disease Study 2010. Lancet. 2012; 380:2224-60. http://dx.doi.org/10.1016/So140-6736(12)61766-8

\section{Uticaj zagađenja vazduha na obolijevanje stanovnika Republike Srpske}

\section{SAŽETAK}

Uvod: Zagađenje vazduha nastaje zbog emisije štetnih gasova i čestica koji su rezultat uglavnom ljudskih aktivnosti, ali i emisije iz prirodnih izvora.

Cilj rada: Cilj ovog istraživanja je bio da se ispitaju najčešći zagađivači vazduha u Republici Srpskoj i njihov uticaj na zdravlje stanovništva, kao i poređenje dobijenih rezultata sa evropskim i svjetskim podacima.

Ispitanici i metode: Koristili smo deskriptivni studijski pristup za analizu zdravlja stanovništva u Republici Srpskoj. Podaci su dobijeni iz izvještaja Instituta za javno zdravstvo Republike Srpske za period od pet godina.

Rezultati: Stanovništvo Republike Srpske najčešće obolijeva od kardiovaskularnih bolesti, a zatim od neoplazmi. Najčešći zagađivači vazduha u Republici Srpskoj su: sekundarne čestice, azotni oksidi, ozon, sumpor dioksid, policiklični aromatični ugljovodonici, benzen, 1,3-butadien, ugljen-monoksid i olovo.

Zaključak: Imajući u vidu patofiziološke mehanizme kojima zagađen vazduh učestvuje u nastanku i pogoršanju kardiovaskularnih, respiratornih, malignih i drugih oboljenja, kao i njihovu zastupljenost u našoj populaciji, može se povući paralela između kvaliteta vazduha u Republici Srpskoj i trenda obolijevanja njenog stanovništva. 